it proceeded on the assumption that railways are permanent and can always be made profit-earning by regulating rates. In Great Britain, road finance has proceeded on sounder lines, as highway expenditure has been met largely out of current expenditure. The ill-conceived legislation which has introduced rigidity into railway rates, wages, hours and conditions of labour has hindered progress to recovery. Co-operation between all kinds of transport is necessary, and rigidity is fatal to it. The closing down of non-paying railways and their conversion into roads should be encouraged. In the discussion, Mr. C. Erlund stated that an enormous saving could be effected so far as goods are concerned, by electrifying several of the main-line railways. This makes electrification a far more attractive proposition than it appears in the Weir Report.

\section{A Modern Japanese Power Station}

Since the inception of the Kyushu Hydro-Electric Railway Co. Ltd. about twenty years ago, the policy of using steam power in Japan as distinct from hydro-electric power has thoroughly justified itself. A description is given of their new 50,000 kilowatt steam generating station, in the Metropolitan Vickers Gazette for October. It was completed in September 1931 having taken little more than a year to construct. The total cost of this station is much lower for its output than any station previously built in Japan. The main buildings are heavy steel structures designed with a view of resisting earthquakes and the walls of the building are of corrugated sheet steel. The chief coal supply is transported by land, the power station being quite close to the main railway line. Special arrangements have been made to minimise the labour and time involved in handling coal. The flue gases are thoroughly cleansed before emission into the air. The larger particles of grit are caught in mechanical collectors and the fine dust and fumes are washed by high-pressure water sprays. The molten slag is tapped from the furnaces, broken into fine pieces by strong water jets, and removed by pump sluicing. The two steam turbine generating sets having outputs of $25,000 \mathrm{kw}$. at 11,000 volts were made by the Metropolitan-Vickers Electrical Co. Ltd. Electroflo steam instruments are used and Kent, Negretti, Siemens, Kelvin, Cambridge and Bailey boiler instruments have been installed. It is interesting to notice that power is transmitted to a substation at 22,000 volts by cables of the Emanueli oil-filled type, paper insulated with a double sheathing of lead.

\section{Fur-bearing Animals in Michigan}

REFERENCE to some results of Dr. Ned Dearborn's investigation into the food of predatory fur-bearing animals in Michigan has already been made in these columns (Dec. 17, 1932, p. 905). The pamphlet (62 pp.) in which the results appear, initiates, with the title of Bulletin $I$, a series of publications by the School of Forestry and Conservation in the University of Michigan, which will contain for the most part the results of studies by the Bureau of Forest
Research. Conditions as regards the fur-bearing animals have changed much since the early days of colonisation, and although Michigan still ranks third amongst the States in fur production, the destruction of the forests -hard-woods and soft-woods in the north, nut-trees in the south-and the draining of the swamps, have vastly reduced the numbers of fur-bearers. It is said that the numbers are not half what they were twenty-five years ago; even the weasel (Mustela noveboracensis) is no longer common in many localities, and the only upland fur-bearer which has held its own is the skunk. It may seem strange that while in Britain we are engaged in a war of extermination against that new invader, the musk-rat, Dr. Dearborn should regret its disappearance with the draining of Michigan marshes for agricultural purposes. He says that in some cases marshes are now more profitable for the musk-rat fur they produce than they would be for agriculture if drained, and cites the case of a drained marsh near Athens in Calhoun County which to-day is said to be worth no more than a single crop of musk-rats would be were it still undrained. "As matters now stand," he writes, "it behoves the owners of marshes to consider well before attempting to drain them". Other conditions, other advice!

\section{Preservation of Fossil Bones}

THE difficulty of preserving fossil bones found in deposits of the later phases of the Ice Age or more recent beds is known to collectors and museum curators; often enough the bones crumble to dust after a night's exposure to the air. Much can be done by immediate attention to preserve such relics for examination and permanent exhibition, and a paper on the "Bakelite Impregnation of Fossil Bones" by H. W. Nichols and Phil C. Orr, of the Field Museum of Natural History in Chicago, ought to be widely known (Museums J., vol. 32, p. 47, May 1932). In the Field Museum, most of the older impregnating materials have been tried, paraffin, glue, gum arabic, shellac, wolfite and several mastics. In some respects these are all deficient. Of the older materials, shellac was found to be the most satisfactory, but Dr. Case's bakelite process is better than any other. Broken bones are cemented with a mixture of plaster of Paris and dextrin, and when the cement is dry, the bone is placed on a screen and lowered gently into a tank of bakelite reduced to a suitable condition of fluidity by the addition of bakelite thinner. The bones thus treated are allowed to dry and the surface cleaned. The greater number of bones require no further treatment, but if a specially strong surface is required the bones may be baked at a temperature of about $208^{\circ} \mathrm{F}$. or more, when the bakelite, under. going polymerisation, gains full strength and becomes no longer soluble in the thinning solution.

\section{Dr. Arnold Berliner}

A spectal issue of Die Naturwissenschaften for December 16 celebrates the seventieth birthday on December 26 of its founder and editor, Dr. Arnold Berliner, It extends to 73 pages, includes scientific 